ПОСТТРАВМАТИЧНИЙ СТРЕСОВИЙ РОЗЛАД УЧАСНИКА
БОЙОВИХ ДІЙ ТА СІМЕЙНА АДАПТАЦІЯ

\author{
POST-TRAUMATIC STRESS DISORDER FOR PARTICIPANT \\ OF MILITARY ACTION AND FAMILY ADAPTATION
}

У статті розглянуто посттравматичний стресовий розлад учасників бойових дій у контексті сімейної адаптації після повернення до умов чивільного життя. Посттравматичний стресовий розлад визначено як відстрочену або затяжну реакцію на стресогенні події чи ситуацію винятково загрозливого або катастрофрічного характеру. Визначено, що відокремлений від сім'ї учасник бойових дій існує як частина мікросоціальної групи, піклується про свою безпеку та безпеку побратимів, натомість члени його сім'ї справляються із робочим і побутовим навантаженням самостійно. Визначено, що в період перебування на військовій службі учасник бойових дій та члени його сім'ї адаптуються до умов життя порізно, тому суттєвою проблемою сімейної динаміки є реінтеграція. Виокремлено фрізичні та емоційні реакції організму на психотравмуючу ситуацію; симптоми важкого стресу та розладів адаптації; симптоми посттравматичного стресового розладу; етапи переживання травматичної ситуації.

Доведено, що сім'я $\epsilon$ вагомим ресурсом підтримки учасника бойових дій у прочесі адаптації. Сорормульовано рекомендації, що спрямовані на психологічну адаптацію та покращення стосунків у сім'ях, які зокрема містять такі положення: членам сім'ї необхідно прийняти та усвідомити зміни, які відбулися або відбудуться у людини, та зрозуміти зміну системи цінностей людини, нові «правила життя» після ії перебування в зоні бойових дій; зауважити, що критерієм для психологічної роботи в сім'ї з учасником бойових дій $\epsilon$ його власна готовність до неї; членам сімї рекомендується не намагатися прискорити події, а дати час, який для нього буде достатнім для адаптації, а також створити умови та сприяти тому, щоб учасник бойових дій знайшов власний спосіб адаптації до мирного життя, а у разі необхідності залучити відповідних фрахівців; створити атмоссреру довіри в сім'ї, з повагою ставитись до особистих меж людини та окреслювати свої, проявляти терпіння, повагу та зберігати спокій.

Ключові слова: адаптація, посттравматичний стресовий розлад, сім'я, сімейна адаптація, учасники бойових дій, психологічна допомога, реінтеграція, травматична cumyauія.

УДК 364.075.71:159.942

DOI https://doi.org/10.32843/2663-

5208.2020 .15 .43

\section{Орловська О.А}

старший викладач

кафедри психології та педагогіки

Таврійський національний університет

імені В.І. Вернадського tence upon their return to civilian life. Post-traumatic stress disorder is defined as a delayed or protracted response to a stressful event or situation of a particularly threatening or catastrophic nature. It is determined that the separated from the family participant exists as part of a microsocial group, takes care of their safety and the safety of their counterparts, but instead his family members cope with work and domestic workload. It is determined that during the military service the combatant participant and his family members adapt to living conditions differently, so reintegration is a major problem of family dynamics. It is established that staying in a combat zone is accompanied by a strong psycho-traumatic influence due to extreme situations in which a combatant enters, which inevitably affects his psychological state - he is experiencing moral and psychological, physical activities that destroy habitual perception, change his or her usual perception.

The physical (insomnia, fatigue, rapid heartbeat) and emotional (negative memories, anger, hatred, excitement, feelings of guilt and hopelessness) of the organism's reactions to the psycho-traumatic situation are distinguished. The symptoms of post-traumatic stress disorder (among them relapse, avoidance and emotional numbness, excessive arousal, strong psychological distress under the influence of external or internal stimuli, symbolizing or reminding aspects of traumatic event, flashbacks, hyperactivity, including difficulty falling asleep and disturbed sleep, difficulty concentrating, excessive vigilance, increased response to strong signals). The stages of experiencing the traumatic situation (phase of denial or shock, phase of aggression and guilt, phase of depression, phase of healing) are given.

It has been proven that the family has been identified as a significant resource to support the combatant in the adaptation process. Recommendations have been formulated aimed at psychological adaptation and improvement of relationships in families, which in particular contain the following provisions: family members need to accept and understand changes that have occurred or will happen in a person and to understand changes in the system of human values, new "rules of life" after being in the war zone; family members are advised not to try to speed things up, but to give them time to adapt, and to create the conditions and help the warrior find his own way of adapting to a peaceful life, to create an atmosphere of trust in the family, respecting the personal boundaries of the individual and outlining their own, displaying patience, respect, and staying calm.

Key words: adaptation, post-traumatic stress disorder, family, family adaptation, combatants, psychological help, reintegration, traumatic situation. 
Постановка проблеми у загальному вигляді. Тема сімейної адаптації учасників бойових дій $є$ актуальною для країн, в яких має або мала місце військова агресія, відбувається військове вторгнення. Останніми роками ця тема актуалізувалася і для України. У зв'язку з актуальними подіями в нашій країні підвищується увага до психологічних аспектів адаптації сімей військовослужбовців після їх повернення із зони бойових дій. Одним із факторів, що впливає на психологічний клімат у сім'ї та взаємини, є характер переживання травматичної ситуації учасником бойових дій, що була пов'язана із виконуваною діяльністю, та його реакція на ці події, а також психотравматичний стресовий розлад, що може проявитися у військовослужбовця.

Аналіз останніх досліджень та публікацій. Проблематика адаптації учасників бойових дій та адаптації їхніх сімей посідає окреме місце у різних галузях досліджень. У руслі психологічних досліджень тема адаптації військовослужбовців посідає чільне місце. Учені Р. Абдурахманов, Л. Вакуленко, Т. Добровольська, М. Зеленова, О. Карояні, Л. Китаєва-Смик, П. Корчемний, В. Маслюк, Є. Миск, В. Попов, Є. Снєдков, С. Сєдін, І. Соловйова, Н. Тарабріна, С. Харченко, А. Єна, Л. Яковлева зосередили увагу на загальнотеоретичних аспектах. Поза межами України тематика адаптації військовослужбовців вивчена чималою кількістю дослідників, серед яких слід відзначити наукові доробки С. Вільямс, Дж. Вілсона, Л. Калхуна, Д. Кишбог, Р. Лауфера, Р. Скурфілда, В. Холла.

Розгляд психологічного складника стану особистості після перебування у зоні бойових дій досліджено у численних роботах О. Блінова, О. Бойка, А.

Бородія, О. Буковської, В. Крайнюка, Є. Литвиновського, М. Мушкевич, А. Романишина та інших. Автори С. Басараб, О. Буковська, С. Васильєв, В. Гічун, О. Друзь, Л. Жаліло, А. Караян, В. Князевич, М. Кравченко, Л. Кудрик, А. Кучер, М. Локтєв, І. Мульована, О. Напрєєнко, І. Сиромятніков, О. Сироп'ятов, Ю. Сурмяк, О. Тополь, Р. Торговицький, О. Філатова, А. Чаплигін займались вивченням проблематики реадаптації учасників антитерористичної операції.

Поява значних складнощів в адаптації учасників бойових дій до умов цивільного життя призводить до формування специфічних відносин у сім'ї, що потребує теоретичного осмислення та практичного вивчення. Протікання адаптації може ускладнитися у зв'язку із посттравматичним стресовим розладом учасника бойових дій. Необхідним $€$ висвітлення особливостей цього стану та розробки рекомендацій для членів сім'ї.
Мета статті. Метою статті є розгляд особливостей феномена посттравматичного стресового розладу учасників бойових дій у контексті сімейної адаптації після повернення до цивільного життя.

Виклад основного матеріалу. Визначимо базові поняття дослідження. «Посттравматичний стресовий розлад" визначається як відстрочена або затяжна реакція на стресогенні події чи ситуацію винятково загрозливого або катастрофічного характеру, які можуть зумовити дистрес майже у будь-кого [15, с. 10]. Поняття «адаптація» визначається як формування найбільш адекватних стереотипів поведінки в умовах змінюваного мікросоціального середовища [2, с. 60]. Поняття «адаптація учасників бойових дій» формулюємо як процес пристосування особистості до нових умов соціального середовища через оволодівання нормами поведінки, пристосування до вимог суспільства. Аспект сімейної адаптації розглядається нами як процес адаптації членів сім'ї учасника бойових дій до нових умов взаємного існування після його повернення до цивільного життя. Дослідник Ю. Бриндіков переконаний, що «успішна адаптація залежить не тільки від зовнішнього середовища, соціального оточення і фізіологічних процесів, але і від особистісних структур, властивостей, характеристик, однією з яких є емоційна стійкість, що забезпечує безпеку особистості, а отже, і психологічну адаптацію» [4, с. 74]. На думку С. Денисюка та В. Корнієнко, основними завданнями адаптації учасників бойових дій $\epsilon$, зокрема, здійснення заходів для пом'якшення наслідків, пов'язаних зі звільненням військовослужбовців і їх адаптацією; створення умов і можливостей для здобуття освіти, перепідготовки та працевлаштування; вдосконалення законодавства про права, пільги та соціальні гарантії громадян, звільнених 3 військової служби, та членів їхніх сімей; вдосконалення механізмів та інститутів соціальної адаптації військовослужбовців [6, с. 112].

У період перебування особистості на військовій службі (окремо від близького оточення) кожен живе різним життям, усі адаптуються до умов життя порізно. Відокремлений від сім'ї військовослужбовець у зоні бойових дій набуває нової діяльності: він функціонує як частина мікросоціальної групи, піклується про свою безпеку та безпеку побратимів. Натомість члени його сім'ї справляються із робочим і побутовим навантаженням самостійно. «Тривалість розлуки на рік чи більше закріплює ці «різні» способи життя» [13, с. 81]. Тому неминучим аспектом сімейної динаміки є реінтеграція. Після завершення служби учасник бойових дій повертається до цивільного життя, до проживання разом із сім'єю. Цей момент 
возз'єднання членів сім'ї є довгоочікуваним, проте може ускладнитися психологічним станом після пережитого досвіду. 3 огляду на складний процес адаптації учасники бойових дій потребують підтримки, в такому разі сім'я $€$ вагомим ресурсом. Важливість підтримки та емпатії членів сім'ї у період адаптації не піддається сумніву, оскільки для більшості учасників бойових дій «сім'я служить компенсуючим чинником у професійній діяльності і відіграє роль емоційного притулку» [10, с. 252].

Перебування в зоні бойових дій супроводжується сильним психотравмуючим впливом через екстремальні ситуації, в які потрапляє учасник бойових дій, що неминуче впливає на його психологічний стан. «Військові дії на Сході України спричинили появу особливої категорії військовослужбовців, які відчули на собі негативний вплив комплексу інтенсивних тривало діючих стресогенних факторів, що призводять до проявів стресів, посттравматичних стресових розладів (ПТСР), емоційних розладів» [3, с. 69]. Військовослужбовці - учасники бойових дій переживають морально-психологічні, фізичні навантаження, що руйнують звичне сприйняття, змінюють поведінку. У контексті такої теми доречно навести визначення травматичного стресу Н. Лозінської, який авторка інтерпретує як «особливу форму загальної стресової реакції, за якої стрес перевантажує психологічні, фізіологічні, адаптаційні можливості людини і руйнує захист» [10, с. 29].

Стосовно наявності хронічного посттравматичного стану як реакції на вплив стресових факторів низка досліджень виявляють приблизно 25-30\% таких військовослужбовців, що брали участь у бойових діях [9, с. 67]. Ключовим тут $€$ наявність тривалого впливу стресового фактору (учасники бойових дій перебувають саме в таких умовах), тому не випадково посттравматичний стресовий розлад називають «хронічним військовим неврозом»: комбінація насамперед психотравми внаслідок екстремальних подій, особливості роботи людської психіки і вплив соціального середовища [12, с. 39] можуть спричинити такі реакції організму:

фізичні реакції (людина потерпає від безсоння, відчуває постійну втому; має проблеми зі шлунком та вживанням їжі; їі супроводжує головний біль та пітливість у разі думки про війну; має швидке серцебиття і дихання; можуть загостритися наявні захворювання);

емоційні реакції (людина бачить погані сни, сняться кошмари; виникають часті негативні спогади про війну; емоції злості та ненависті; відчуття безпорадності, страху, нервування; відчуття суму, самотності, непотрібності; відчуття збудження, схвильованості; відчуття шоку, оніміння, неможливості відчувати позитивні емоції; легко погіршуваний настрій; почуття провини, сорому, самосуду; почуття безнадії щодо майбутнього) [1, с. 9-10].

Більш загальну класифікацію представляє дослідник Р. Кадиров, виділяючи такі реакції: психологічні реакції, дезадаптивні реакції, гострі афективні реакції, психоневротичні реакції, патохарактерологічні реакції, гострі реактивні реакції [8, с. 36].

В Уніфікованому клінічному протоколі медичної допомоги у посттравматичного стресового розладу визначаються такі симптоми: повторне переживання - характеризується нав'язливими тривожними спогадами про травматичну подію; кошмарами; інтенсивними психологічними стражданнями або соматичними реакціями, такими як підвищене потовиділення, прискорене серцебиття та паніка у разі нагадування про травматичну подію; уникнення і емоційне заціпеніння характеризується уникненням занять, місць, думок, почуттів або розмов, пов'язаних з подією; загалом обмеженими емоціями; втратою інтересу до звичайної діяльності; відчуттям відстороненості від інших; надмірне збудження - характеризується безсонням, дратівливістю, труднощами із концентрацією уваги, надмірною настороженістю, надмірним старт-рефлексом [15, с. 10]. Якщо військовослужбовець переживає посттравматичний стресовий розлад, то у нього, вірогідно, проявляється один із цих типів симптомів, якими характеризується розлад. Прояви наслідків організму на психотравмуючу ситуацію можуть виникати одразу, а можуть бути реакціями відстроченого характеру, адже, як стверджують дослідники О. Буряк, М. Гіневський та Г. Катеруша, «посттравматичний синдром - це бомба уповільненої дії, він може проявитися через півроку, а може і через десять років» [5, с. 178].

Дослідниця Л. Матвієць звертає увагу на те, що в ході надання психологічної допомоги фахівець має проаналізувати динаміку переживання травматичної ситуації військовослужбовцем та її етапи. Так, авторка виділяє: І етап - фаза заперечення або шоку - настає одразу після дії травматичного фактору, характеризується тим, що людина емоційно не може прийняти подію, яка відбулася (спрацьовує захисна функція психіки від деструктивної дії травматичної ситуації через заперечення або несприйняття); II етап - фаза агресії і провини - людина починає осмислювати травмуючу подію, що відбулася, може намагатися зрозуміти її причини, шукати винних у цьому, переживати провину, направляти агресію на себе; III етап - фаза депресії - характеризується усвідомленням того, що обставини виявилися сильнішими, це супроводжується почуттям безпорадності, безпомічності, власної непотрібності, відсутності мети подальшого життя; може втрача- 
тися інтерес до спілкування, людина може не проявляти зацікавленості у комунікації із оточуючими, що посилює відчуття самотності, незрозумілості іншими людьми; IV етап - фаза зцілення - характеризується сприйняттям пережитих травмуючих подій, усвідомленням та прийняттям минулого, набуття нового сенсу існування [9, с. 8].

Група дослідників особливостей реабілітації учасників бойових дій відзначають, що у 100\% випадків особи з посттравматичним стресовим розладом наголошують на психологічних проблемах взаємин з оточуючими, насамперед з членами сім'ї [7, с. 7]. 3 огляду на непростий період адаптації, який може ускладнитися через посттравматичний стресовий розлад військовослужбовця, ми сформулювали список рекомендацій членам сім'ї, які спрямовані на покращення стосунків: 1) Прийняти та усвідомити зміни, які відбулися або відбудуться у людини, яка повернулася із зони бойових дій. 2) Члени сім'ї мають зрозуміти зміну системи цінностей людини після іï перебування в зоні бойових дій. 3) Члени сім'ї мають усвідомити нові «правила життя», які сформувались в учасника бойових дій. 4) Критерієм для психологічній роботи в сім'ї з учасником бойових дій є його власна готовність до неї. 5) Членам сім'ї рекомендується не намагатися прискорити події, а дати час, який для нього буде достатнім для адаптації. 6) Створити умови та сприяти тому, щоб часник бойових дій знайшов власний спосіб адаптації до мирного життя і у разі необхідності залучити відповідних фахівців. 7) Створити атмосферу довіри в сім'ї. 8) Члени сім'ї мають розуміти, що довіра військовослужбовця до них і до побратимів відрізняються за смисловим значенням. 9) Членам сім'ї необхідно з повагою ставитись до особистих меж колишнього військовослужбовця та окреслювати свої. 10) Члени сім'ї мають проявляти терпіння, повагу та зберігати спокій. Ми впевнені, що виконання цих рекомендацій може суттєво вплинути на взаємини в сім'ї в період адаптації.

Висновки та перспективи подальших досліджень. Таким чином, процес сімейної адаптації учасників бойових дій до умов мирного життя $є$ складним процесом пристосування до нових умов існування. Пережитий досвід специфічної діяльності позначується на психологічному стані учасника бойових дій. Адаптація може ускладнитися посттравматичним стресовим розладом військовослужбовця, прояви якого неодмінно впливають на характер взаємин із близьким оточенням. Однак сім'я $є$ потужним ресурсом підтримки в складний адаптивний період. Розроблені рекомендації для членів сім'ї можуть позитивно вплинути на перебіг цього процесу. Проте все ще залишаються не досить роз- критими техніки та арт-практики для роботи із учасниками бойових дій для усунення посттравматичного стресового розладу.

\section{ЛІТЕРАТУРА:}

1. Акименко Ю.Ф., Сила Т.І. Як допомогти родині учасника бойових дій : методичний посібник для соціальних працівників і психологів. Чернігів : Десна Поліграфр, 2017. 144 с.

2. Безпалько О. Соціальна педагогіка в схемах і таблицях : навчальний посібник. Київ : Центр навчальної літератури, 2003. 134 с.

3. Бриндіков Ю.Л. Організаційно-педагогічні умови дієвості реабілітаційної діяльності 3 військовослужбовцями Збройних сил України, що брали участь у бойових діях. Вісник Університету імені Альфрреда Нобеля. Серія Педагогіка і психологія. 2018 . № 1 (15). С. 69-75.

4. Бриндіков Ю.Л. Теорія та практика реабілітації військовослужбовців - учасників бойових дій у системі соціальних служб : дис. ... д-ра пед. наук : 13.00.05. Тернопіл. нац. пед. ун-т ім. Володимира Гнатюка. Тернопіль, 2019. 559 с.

5. Буряк О.О., Гіневський М.І., Катеруша Г.Л. Військовий синдром «АТО»: актуальність та шляхи вирішення на державному рівні. Збірник наукових праць Харківського університету Повітряних Сил. 2015. Вип. 2. С. 176-181.

6. Денисюк С.Г., Корнієнко В.О. Адаптація як передумова самореалізації військовослужбовців до умов цивільного життя. Актуальні проблеми проєктування, виготовлення і експлуатації озброєння та військової техніки : матеріали Всеукраїнської науково-технічної конореренції. Вінниця, 17-19 травня 2017 р. Вінниця : ВНТУ, 2017. С. 111-113.

7. Єна А.І., Маслюк В.В., Сергієнко А.В. Актуальність і організаційні засади медико-психологічної реабілітації учасників антитерористичної операції. Науковий журнал МОЗ України. 2014. № 1. С. 5-16. URL: http://nbuv.gov.ua/UJRN/njmoz_2014_1_4 (дата звернення: 03.11.2019).

8. Кадыров Р.В. Посттравматическое стрессовое расстройство (PTSD): состояние проблемы, психодиагностика и психологическая помощь : учебное пособие. Санкт-Петербург : Речь, 2012. 448 с.

9. Кучеренко С.М, Хоменко Н.М. Організаційні особливості соціально-психологічної адаптації військовослужбовців, які брали участь у бойових діях, до умов мирного життя. Проблеми екстремальної та кризової психології. Збірник наукових праць. Вип. 21. Харків : НУЦ-3У, 2017. С. 66-74.

10. Лозінська Н.С. Особливості психологічної травматизації військовослужбовців-учасників АТО : дис. ... канд. псих. наук : 19.00.09. Нац. ун-т. цивільного захисту України. Харків, 2019. 260 с.

11. Матвієць Л.Г. Організація та моніторинг своєчасного надання медико-психологічної допомоги на первинному рівні при гострих та посттравматичних стресових розладах. Семейная медицина. 2017. № 5. C. 6-11.

12. Олексюк Н. Позитивна спрямованість сімейних взаємин як вагомий чинник життєдіяльності сімей військовослужбовців Збройних сил України. Проблеми сучасної психології. 2009. Вип. 4. С. 249-258. 
13. Основи реабілітаційної психології: подолання наслідків кризи : навчальний посібник / За заг. ред. Н. Пророк. Том 1. Київ, 2018. 208 с.

14. Павлик Н.В. Психологічна адаптація особистості в екстремальних умовах військової діяльності. Наук.-дослід. центр гуманітарних проблем 3б. сил України. 2005. Т. 8. № 4. С. 37-41.
15. Унісрікований клінічний протокол первинної, вторинної (спеціалізованої) та третинної (високоспеціалізованої) медичної допомоги, реакція на важкий стрес та розлади адаптації. Посттравматичний стресовий розлад. 2016. URL: http://mtd.dec.gov.ua/ images/dodatki/2016_121_PTSR/2016_121_YKPMD_ PTSR.pdf. (дата звернення: 03.11.2019). 